\title{
THE PROPOSAL FOR INTEGRATED ICT SOLUTION FOR THE ENFORCEMENT OF MONETARY CLAIMS AGAINST A JUDGMENT DEBTOR - NATURAL PERSON IN MONTENEGRO
}

\author{
Dejan Abazović ${ }^{1}$ \\ Andrija Jovović2 \\ Budimir Lutovac ${ }^{3}$ \\ ${ }^{1}$ Central Bank of Montenegro, Head of IT \\ Podgorica, Montenegro \\ ${ }^{2}$ Central Bank of Montenegro, \\ Head of Payment System, \\ Podgorica, Montenegro \\ ${ }^{3}$ University of Montenegro, \\ Faculty of Electrical Engineering, \\ Podgorica, Montenegro
}

\begin{abstract}
:
Bearing in mind the problems currently occurring in the functioning of enforcement against monetary claims (hereinafter: enforced collection) of a judgment debtor - natural person, this paper presents a proposal for a project design which would resolve the main existing problems. The project design is based on the concept of implementation of an integrated information and communications technology (ICT) system which would generally include all the writs of enforcement against judgement debtors - natural persons. The ICT system would be implemented in the Central Bank of Montenegro. Employers would pay wages arising from personal income in two instalments, the first of which would represent the funds excluded from enforced collection, while the second would be available for collection. The implementation of this proposal would require amending the existing regulations, finalizing the manner of the processing of personal income with the employer, as well as recording natural persons' earning with commercial banks. In addition, this solution includes the adjustment of both the organization and system of the issuer of the writ of enforcement, because all the writs of enforcement would be submitted to the Central Bank of Montenegro electronically.
\end{abstract}

Key words:

enforced collection against natural persons, enforced collection, the centralized processing of enforcements, Central Registry of Enforced Collection, ICT system of enforced collection.

\section{INTRODUCTION}

The enforcement against monetary assets (hereinafter: enforced collection) at the account of the judgment debtor or sole trader represents a legal obligation and the power of the Central Bank of Montenegro (CBM) to ensure the settling of the obligation stated in the grounds for enforced collection for the benefit of the transaction account of the judgment creditor, from all transaction accounts pertaining to the judgement debtor in which there are funds, according to the time of receipt of the said grounds for the enforced collection, under the rule of law. The enforced collection is levied pursuant to numerous regulations, the Law on Enforcement and Securing of Claims being the most important among them (Decision on Determining E-messages for levying Enforced Collection).

While the process of enforced collection against the account of a legal entity or sole trader is levied completely synchronously with the use and utilization of information communication technologies (ICT), organized as a integrated information system, the process of enforced collection 
against natural persons is levied asynchronously with multiple entities, without uniform approach and with numerous problems. The problems in the process of enforced collection against natural persons occur in all entities involved in the process: the issuer of the writ of enforcement, commercial banks, employers, and finally the judgement debtors.

A hierarchical description of the system, in the technique diagrams of data flows, comes down to the fact that at higher levels are defined global processes, and then to the next level down, new data flow diagram. Because of this, in accordance with the method of Structural System Analysis (SSA), we opted for a data flow diagram at the top of this hierarchy, which is called context diagram (Faculty of Organizational Sciences, 2000) .

This paper presents a proposal of the project design for the establishment of uniformly organized ICT system of enforced collection against natural persons. The system would be implemented in the Central Bank of Montenegro (CBM) while the process of enforcement would be implemented exclusively in commercial banks, similarly to the corresponding process for legal entities and sole traders. This conceptual solution would encompass all the issuers of writs of enforcement in Montenegro.

Preconditions for its implementation include amending the Law on Enforcement and Securing of Claims, finalizing the manner of wage processing of the employer, as well as changing the manner of recording monetary assets in the transaction accounts of natural persons in commercial banks.

\section{ENFORCED COLLECTION AGAINST THE ACCOUNTS OF LEGAL ENTITIES AND SOLE TRADERS}

The ICT system (IS PNPL) was established for the implementation of enforced collection against the accounts of legal entities and sole traders. The system has been in operation in the CBM since 2008.

The Central Registry of Transaction Accounts (CRTR) for legal entities is kept within the IS PNPL. As of 30 June 2012, the data on the number of legal entities and sole traders recorded in CRTR are harmonized with the data on active legal entities and sole traders recorded in the Central Registry of Business Entities (CRPS), on a monthly basis.

As at 31 January 2016, the Central Registry of Transaction Accounts included 77,208 legal entities and sole traders, which is a $0.30 \%$ increase in relation to 31 De- cember 2015, when this number was 76,973. Updating of other data published in relation to the levying of enforced collection is done accordingly.

The IS PNPL was updated on multiple occasions, with the final major update done in 2013. Through its implementation, the process of enforced collection against the accounts of legal entities and entrepreneurs was completely based on ICT (Indicators of enforced collection).

The ICT system of enforced collection against the accounts of legal entities and sole traders is implemented in the CBM, which is connected with the commercial banks in Montenegro through a business network. The enforcement of the basis for the enforced collection is done through the exchange of e-messages between the CBM application systems and commercial banks. Special transaction system functioning on the principle of SWIFT messages was developed for the purpose of message exchange (Figure 1). The structure of messages and their content are defined in the internal document of the CBM - "Decision on Determining E-messages for levying Enforced Collection".

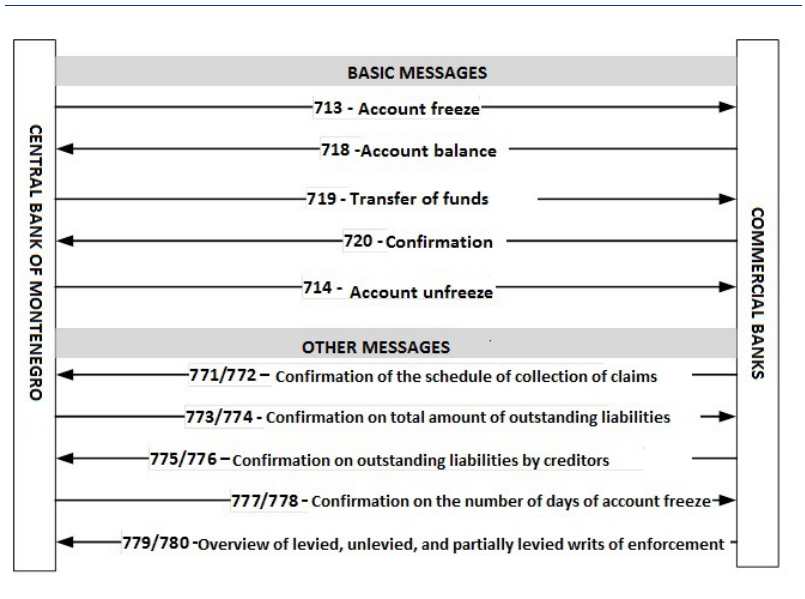

Figure 1. Transaction system for message exchange

Tax identification number (PIB) of legal entities represents their main identifier, while for the sole traders it is the personal identification number (JMB) of the natural person performing the registered business. Upon receiving the writ of enforcement, the $\mathrm{CBM}$ initiates the enforced collection proceedings by freezing all the accounts of the legal entity or sole traders (hereinafter: judgement debtor) with commercial banks. At the same time, other banks cannot open new accounts for the judgment debtor. Upon receiving the confirmation of the freezing of the account, the CBM receives data on the balance of funds on such account. On the basis of the previously defined algorithm for the collection of 
funds from the transaction accounts, the CBM orders the commercial banks to transfer the funds from the frozen account of the judgement debtor to the account of the judgement creditor. Upon completion of the enforced collection procedure, the CBM orders the banks to unfreeze the account of the judgment debtor.

With regard to enforced collection against the legal entities and sole traders, pursuant to the Payment System Law, the CBM is obliged to publish the names of legal persons and/or sole traders, their register/personal identification numbers, the frozen amounts, and the number of days of uninterrupted account freeze. The names of legal persons are taken from the CRPS. The CBM publishes the above mentioned data on a monthly basis, with the balance as at the last day in the previous month (Law on Payment Transactions).

The CBM publishes the above mentioned data on a monthly basis on its website on the first business day of the following month in alphabetical order. The identification numbers for sole traders are not published because their transaction accounts are recorded in the CRTR under their personal identification number (JMB), and publishing this number is not in line with the Personal Data Protection Act.

In 2015, the CBM developed e-service which enabled all the legal entities in Montenegro, whether they are judgement debtors or creditors, to acquire necessary information regarding the enforced collection in a manner compliant with the Law on Enforcement and Securing of Claims. The main prerequisite is the possession of qualified digital certificate. In this manner, pursuant to the Law on Electronic Signature, the authentication of the legal entity requesting the data from the CBM system is performed on the e-portal.

\section{ENFORCED COLLECTION AGAINST NATURAL PERSONS}

\subsection{CURRENT SITUATION AND OPERATIONAL ISSUES}

Pursuant to the latest amendments to the Law on Enforcement and Securing of Claims, the CBM is obliged to keep the CRTR of natural persons. Upon the establishment, as at 3 August 2015, the CRTR of natural persons was also made available in the form of e-service via internet on the e-portal of the CBM.

The enforcement officers and other competent state authorities acquire data on the transaction accounts of natural persons - judgement debtors based on written communication or using the e-portal of the CBM.
The process of the enforced collection against natural persons is implemented completely asynchronously, without uniformly arranged and organized system.

There are many problems occurring in the process of enforced collection against natural persons, arising with all the participants in the collection process. Pursuant to the Law, the enforced collection is levied through prohibition and pay out. Basically, in majority of issuers of the writs of enforcement, the process is carried out as follows:

- Pursuant to the Law on Enforcement and Securing of Claims, the enforcement against wages is conducted with the employer. In order to levy the enforced collection in such manner, the issuers of the writs of enforcement receive from the Tax Administration of Montenegro the information on whether the judgment debtors are employed, and if so, who is their employer. Upon receiving such information, the issuer of the writ of enforcement submits to the employer a writ of enforcement, which the employer is obliged to comply with.

- These data are often unavailable or outdated. In those cases, it is checked whether the judgement debtor is in the Pension and Disability Fund's records (PIO Fund). If it is so, the Fund is delivered the writ of enforcement.

- If the judgement debtor is not in the PIO Fund records, the issuers of the writ of enforcement acquire information on the banks where the judgement debtor has opened transaction accounts. Upon receiving information on transaction accounts, the issuers deliver the writs of enforcements to the banks. Public enforcement officers receive data on the transaction accounts in paper or electronic form from the CRTR of the CBM.

- In the situations referring to traffic offences, the issuers (Ministry of Interior, misdemeanor courts) deliver the final uncollected writs of enforcement to the Register of Fines, following the described procedure. In these cases, the persons prosecuted or fined for the traffic offences, shall not be allowed: a) to register or extend the registration of the motor vehicle, and b) to be issued or to extend the validity of a drivers license, until they have paid all fines and court costs recorded in the Register of Fines.

This manner of enforcement levying does not apply to the funds found on the judgement debtor's account arising from wages. Commercial banks encounter problems with regard to "recognizing" such funds in the account, therefore it often happens that both the employer and the 
bank withhold funds arising from wages. In such situations, the return of funds to the judgement debtor can be lengthy and complicated.

It happens very often that some commercial banks do not respond to the demands of issuers of the writ of enforcement or that the issuer of the writ of enforcement does not have the information on whether the writ of enforcement is carried out. In most cases, the process of implementation of the writ of enforcement lasts for days while the law prescribes that the writ of enforcement must be carried out without delay.

As the main form of communication between the issuer of the writ of enforcement and the bank is in the written form, which often requires significant time, the situation at the transaction account is often changed. In addition, due to the written communication, freezing of the account of the judgement debtor can last for a very long time despite the fact that the judgement debtor has sufficient funds for the payment.

It often happens that a large number of cases, the writ of enforcements, remain in backlog before the misdemeanor courts for a long period of time. In this way they acquire conditions to become obsolete, which makes courts inefficient.

Given that the commercial banks where the judgement debtor has no transaction account do not have information on writ of enforcement, it is possible that the judgement debtor, while his transaction account is frozen with one commercial bank, opens the transaction account with other commercial bank, thus avoiding the enforced collection.

Recording of received writ of enforcement and actions with commercial banks is a very complex process. Tens of thousands of writ of enforcements in individual commercial banks is monitored and they are mostly treated without orderly IT process. Banks are exposed to the need for additional employment risk and expenditures risk. Also, due to the enforced collection against natural persons' accounts, reputational risk of a commercial bank is very high. Consequently, it results in a higher number of requests for closing the transaction accounts of their clients, natural persons.

In cases of the execution of enforced collection through the offence warrant (order) of the Ministry of Interior Affairs, due to traffic offense, which is in most cases implemented with the employer, writ of enforcement is often carried out after several years. By this, the meaning of the sentence and changes in behavior of perpetrators of this type of offense are completely lost.

\subsection{PROPOSAL OF PROJECT DESIGN}

Accordingly, the execution of the enforced collection from natural persons must be organized through uniform information system (IS PNFL - Information System of Enforced Collection from Natural Persons), the implementation and management of which is under the responsibility of the CBM. This writ of enforcement would allow the enforced collection from natural persons in a unique manner.

The IS PNFL would include all issuers of writs of enforcement that would be delivered electronically for the enforcement. The processing of the enforcement as well as the coordination and implementation of all activities related to enforced collection would create conditions for the establishment of the Central Registry for Enforced Collection (CRPN). Such an organized and regulated CRPN would allow all types of statistical analysis and insight into the balance of the enforced collection, regardless of whether it is a debtor or creditor, for legal and natural persons.

The enforced collection from natural persons would be implemented in commercial banks in which the judgement debtor has transaction accounts. All earnings made by a debtor can be summarized only at the transaction accounts with commercial banks. Primarily, it refers to earnings based on the right on personal income or fees realized on various grounds. Similarly, this applies to all other earnings and acquired rights to compensation (welfare assistance, child allowance, disability allowance, and the like).

Employers would divide wages divided into two parts (Figure 2), in accordance with the Law on Enforcement and Securing of Claims. The first part of the wage would represent funds exempted from the enforced collection. The second part of the wage would represent funds that are available to the enforced collection.

For each employee, the employer would send information on wages to commercial bank in two parts. Based on this information, the commercial bank would keep records on all wages of the transaction account holder in the supporting table. If the recipient of funds is not subject to the enforced collection, commercial bank would not have to keep records on the type of earning (free/available for enforced collection).

If the judgment debtor has other earnings, for example on the basis of service contract, on the basis of his participation in the work of a board of directors and the like, these funds would be transferred under the type "funds 
available for the enforced collection", but also the commercial bank would not have to record the type of earnings if the recipient is not subject to enforced collection.

If the debtor has earnings realized on the basis of welfare assistance, child allowance, and the like, those earnings would be transferred under the type "free", but also the commercial bank would not record the type of earnings if the recipient is not subject to enforced collection.

All other earnings would be also transferred under the form defined by the legislator, while the commercial bank would not have to record the type of earnings if the recipient is not subject to the enforced collection.

Once the commercial bank receives the message that the client is subject to the enforced collection, the commercial bank reserves the funds held at the account for the purpose of the enforced collection in the amount defined by the legislator (for example: funds available for the enforced collection are all funds at the account holder above the minimum wage in the state or the like).

Thus, for each subsequent inflow, depending on the type of earnings, the commercial bank allows the account holder to dispose of those funds or reserves them for the enforced collection, until obtaining the message on the termination of the.

If a commercial bank for the same client again obtains a message for the enforced collection, the present funds would be treated in the same way as the first time.

Unless transaction account holder is not subject to the enforced collection procedure, he/she manages all the funds at the transaction account in a regular manner.

\subsection{DATA FLOW DIAGRAM}

Data flow diagram is a model system that consists of four basic components: data processing (the active component of the system), objects environment (interface) with which system communicates, data warehouse which processes use and / or update and the data flows which connect other components in the whole system (Structural System Analysis).

The main characteristics of data flow diagrams are:

- clear graphics specification, suitable for communication with the user,

- clear and detailed description of the system, using the method of abstraction so that the system at higher levels of abstraction describes in general and on the lower detailed level.
Data Flow Diagram - Diagram of context, according to the SSA, is shown in Figure 2.

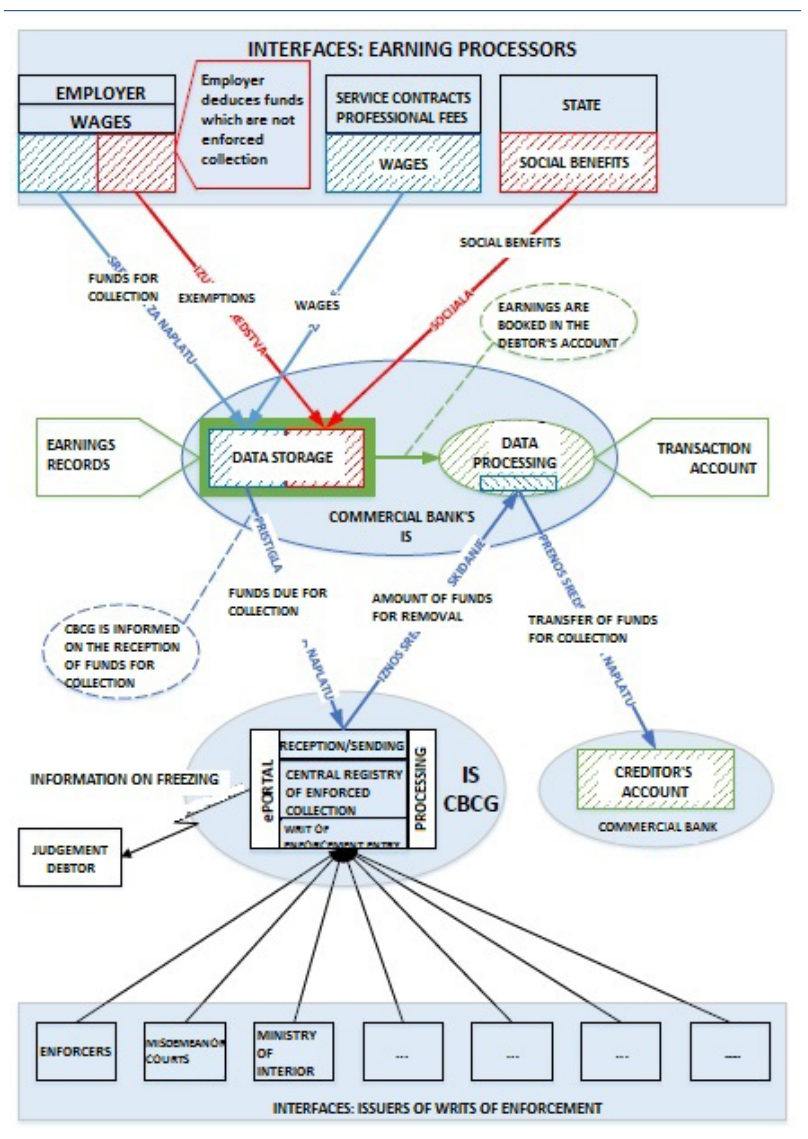

Figure 2. Uniform system of enforced collection from natural persons

The enforced collection at the accounts of natural persons would be realized in the following steps:

1. Upon the receipt of a writ of enforcement, and after the examination, the CBM would forward a message to all banks requiring the freezing of transaction accounts of the debtors. The same message would prohibit the opening of transaction account by the debtor with commercial banks where the debtor does not have a transaction account.

Note: The term "freezing" of transaction account of a natural person as a judgment debtor means that the enforced collection is executed over that transaction account. Judgment debtor remains free to dispose of the funds that are exempt from the enforced collection. Based on this information, the commercial bank would know that the CBM should submit data on inflows of funds available for the enforced collection for that judgment debtor. 
2. After obtaining the confirmation on account freezing, the CBM would receive information from banks on the funds available for the enforced collection. A commercial bank would calculate this amount in relation to the current situation, based on defined legislator's norms.

3. After collecting information from all commercial banks on available funds at the transaction accounts (funds held at the account) for the enforced collection, the CBM would send a message to individual banks with an order for transfer of funds from the transaction account of judgment debtor to the judgment creditor's account. The remaining funds at the transaction account would be at the disposal of the judgment debtor.

4. If the execution of enforced collection could not be fully implemented due to the lack of funds, the judgment debtor's transaction account would remain under the enforced collection - frozen account. In this case, the IS CBM would wait for a message from the commercial bank on the inflow of funds available for the enforced collection. In accordance with registered funds, the commercial bank would submit to the CBM the amount of funds available for the enforced collection. At the same time, the commercial bank would register total amount of funds at the transaction account of the debtor.

Note: Should time period in which funds are registered at the transaction account of the judgement debtor until their removal, on the basis of received message from the CBM, is long enough for the judgment debtor to withdraw them (upon completion of daily work of the IS PNFL or on Saturdays), the commercial bank should reserve these funds.

5. On the basis of the information on the amount of funds at the account that are available for the enforced collection, the CBM (in accordance with the remaining debt) would recalculate and send to a commercial bank a message on the amount of funds for the removal from the judgment debtor's transaction account. The process is repeated until full payment to the judgment creditor.

6. After entirely realized payment, the CBM would send a message to all commercial banks on unfreezing of the transaction accounts.

7. Any creditor and debtor could get at any time the information on the balance of the enforced collection that is in progress via the e-portal, and an overview of the previous enforced collections.

\section{CONCLUSION}

This project design represents the basis for building the IS PNFL and provides guidelines for possible amendments to the Law on Enforcement and Securing of Claims. Lessons learned in the IS PNPL implementation and management were the basis for its development. This project design provides for, with the use of the existing hardware, communication, system and application infrastructure in a fast an efficient and relatively inexpensive way, the planning and organizing of the enforced collection of natural persons' monetary assets in Montenegro.

It is obvious that this proposal for a project design consists of a multitude of processes, interfaces, flows and data warehouses. The specification is complete and clear.

Centralized coverage of all writs of enforcement, regardless of the issuer, and the levy of the enforcement at transaction accounts of the judgment debtor in commercial banks, make the system efficient and effective. In this way the enforcement costs would be reduced to a minimum, the process would be secure and transparent and all entities, participants in the process, would be professionally satisfied. Also, all the elements of social policy would be protected.

In the event that the legislator accepts this proposal, laws and enabling regulations should define the handling of the initial funds i.e. funds held at the transaction account at the time of freezing. Also, all disputable situations should be solved as well as issues related to time deposits, alimony, enforcement against wages that the employer transfers from abroad, and the like.

Also, the CBM should amend the "Instruction on detailed manner of levying the enforcement against monetary assets at the account of judgement debtor" and "Decision on establishing electronic messages for the enforced collection" which defines in more detail the specifications and rules for data exchange between:

- Writ of enforcement issuer and the CBM (electronic exchange of writs of enforcement),

- Employer and commercial bank (form for submitting data on earnings), and

- Commercial bank and the CBM (exchange of messages in the enforced collection proceedings).

Terms of Reference for the development of application should include the processing of the CBM e-portal with amended and new electronic services according to the needs of judgment debtors, issuers and other entities participating in the process of enforced collection. 


\section{REFERENCES}

Centralna banka Crne Gore. (2016). Odluka o utvrđivanju elektronskih poruka za sprovođenje prinudne naplate. Retrieved March 1, 2016 from http://www. cbcg.me/slike_i_fajlovi/fajlovi/fajlovi_brzi_linkovi/ propisi/pr_naplata/odluka_o_elektronskim_porukama.pdf. (In Montenegrin).

Centralna banka Crne Gore. (2016). Pokazatelji prinudne naplate. Retrieved March 1, 2016 from http://www.cbcg.me/index. php?mn1=platni_promet\&mn2=prinudna naplata\&mn3=pokazatelji_prinudne_naplate. (In Montenegrin).

Centralna banka Crne Gore. (2016). Prinudna naplata. Retrieved March 1, 2016 from http://www.cbcg.me/ index.php?mn1=platni_promet\&mn2=prinudna naplata. (In Montenegrin)

E-portal CBM. (2016). Retrieved March 1, 2016 from https://eportal.cbcg.me/
Fakultet organizacionih nauka. (2000). Strukturna sistemska analiza. Beograd: Fakultet organizacionih nauka. Retrieved March 1, 2016 from http://pisbp.fon.bg.ac. rs/download/SSA.pdf. (In Serbian).

Official Gazette of Montenegro. (2011). Law on Electronic Signature No. 55/03 of 01.10.2003, No. 31/05 of 18.05.2005, No. $41 / 10$ of 23.07 .2010 , No. $40 / 11$ of 08.08.2011.

Official Gazette of Montenegro. (2012). Law on Personal Data Protection No. 79/08 of 23.12.2008, No. 70/09 of 21.10.2009, No. 44/12 of 09.08.2012.

Official Gazette of Montenegro. (2013). Law on Payment Transactions No. 62/13 of 31.12.2013, No. 6/14 of 04.02.2014.

Official Gazette of Montenegro. (2015). Law on Enforcement and Securing of Claims, No. 36/11, of 27.07.2011, 28/14 of 04.07.2014, 20/15 of 24.04.2015. 